\title{
UM CONVITE À REFLEXÃO SOBRE O DILEMA "SOCIEDADE OU NATUREZA"
}

\author{
Por Sylmara Lopes Francelino Gonçalves-Dias \\ Professora da PUC-SP. Doutoranda em Administração de Empresas na FGV-EAESP e Ciências Ambientais na PROCAM-USP \\ E-mail: sdias@peoplesolutions.com.br
}

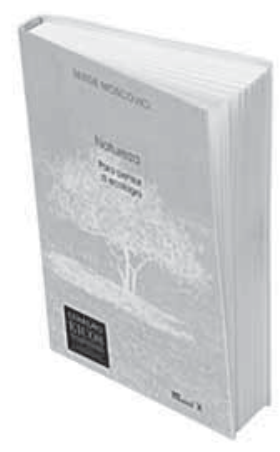

\section{NATUREZA: PARA PENSAR A ECOLOGIA}

De Serge Moscovici

Rio de Janeiro: Mauad X, Instituto Gaia, 2007. 254 p.

N atureza: para pensar a ecologia é o segundo livro de Serge M oscovici, publicado no Brasil pela Coleção EICOS. 0 primeiro foi Crônica dos anos errantes ( Mauad X, Instituto Gaia, 2005), um retrato au tobiográfico que detal ha sua infância e juventude na Romênia até sua chegada em Paris, onde vive hoje. $\mathrm{N}$ a obra atual, $\mathrm{O}$ autor oferece uma retrospectiva do movimento ecológico europeu e das questões epistemológicas, que se encontram nas suas raízes, e propõe uma nova visão do homem, da natureza e da cultura. Para ele, se antes a questão ecológica era local, aos poucos ela se torna universal.

A maioria dos artigos apresentados na obra foi reescrita pelo autor, para exprimir a evolução de seu pensamento e dar conta da experiência que surgiu do contato com novas gerações. É um livro novo, sem nenhuma solu- ção de continuidade com o passado e a época histórica que o amadureceu. Como afirma Pascal Dibieno prefácio, os artigos apresentados na forma de entrevista e conferências "funcionam como uma ampliação da consciência ecológica e política", um convite para que a ecologia "setorne um verdadeiro fenômeno cultural".

0 livro é uma seleção de textos significantes do ponto de vista teórico que marcaram o movimento naturalista e trabalharam a idéia ecologista de "reencantamento do mundo". Esta idéia é recuperada por meio dos temas que Moscovici apresenta num percurso de uma autêntica ecologia política em suas reflexões filosóficas e existenciais.

A atualidade do tema e a personalidade instigante e reflexiva de Moscovici levam-nos a buscar em sua obra o resgate da aliança rompida entre 0 homem e a natureza. A obra reúne 0 pensamento e a militância do psicossociólogo sobre a N atureza e a Ecologia como movimento social epolítico, entre 1970 e 2002, em suas diferentes formas de escrita e entrevistas, e por ela podemos acompanhar suas reflexões no decorrer dos anos.

Serge Moscovici nasceu na Romênia em 1925, foi um dos fundadores do movimento ecológico na França e, em 2000, recebeu um dos mais prestigiosos prêmios europeus de ecologia, o Cervi Ambiente, na Itália. Foi diretor de pesquisa naÉcole des Hautes Études em Sciences Sociales (EHESS) e atualmente dirige o Laboratoire Européen de Psychologie Sociale, da Maison des Sciences de l'H omme, em Paris. $\mathrm{O}$ autor também militou junto ao Les Amis de la Terre, associação fundada em 1970 
visando a ampliar a ação, em rede mundial, do movimento Friends of the Earth, iniciado em 1969 por David Brewer, nos Estados Unidos.

O "naturalismo subversivo" do autor, como qualifica Jean Jacob, em História da ecologia política (Albin Michel, 1999), quer declinar exatamente três palavras: retorno à natureza. Um chamado a revivificar a união entre os homens e a natureza. 0 movimento não diz respeito somente aos estudiosos envolvidos com a ecologia política daquela época. Intelectuais como o seu contemporâneo Edgard M orin no Paradigma perdido: a natureza humana (Publicações Europa-América, 1973) se inspiraram nele para denunciar 0 pensamento contra a natureza. Ilya Pirogine, prêmio N obel de Física, junto com Isabelle Stengers, consideraram por sua vez, em A nova aliança (Universidade de Brasília, 1984), a importância da proposição de M oscovici de reintroduzir a ciência na natureza e levar em conta a "nova natureza" que os homens criam sem cessar.

O filósofo al emão Habermas, refletindo sobre "o pós-Marx", encontrou também em M oscovici o objeto de reflexão sobre a história humana dentro da natureza, notadamente para repensar as forças produtivas que alteram as relações na sociedade. A lista de pesquisadores e pesquisas que foram inspiradas pela obra "naturalista" de M oscovici está longe de encerrar e certamente não cessará de crescer entre aqueles incumbidos de pensar a história das relações dos homens dentro da natureza.

o caminho que 0 autor percorreu pelo movimento da ecologia política demonstra a precocidade da sua inquietação com o esgotamento dos recursos naturais, que ameaça, além das sociedades modernas, a própria sobrevida do homem. Uma análise de seu percurso faz com que possamos falar de um Moscovici sensível evisionário, preocupado com a história e a fil osofia da natu reza, que o levaram a um engajamento político no momento em que poucas pessoas faziam da ecologia um tema de ação política. Pensar a natureza sob a perspectiva do autor "nos leva a reconsiderar a fragilidade da presença humana em harmonia com a natureza", como indica Tânia Maciel, que escreveu o prefácio da edição.

Quando em 1968 foi publicado o Essai sur I'histoire humaine de la nature (Éditeur Flammarion, 1968), na coleção dirigida por Fernand Braudel, a obra foi acolhida com surpresa pela comunidade científica e intelectual. Ela foi vista com curiosidade e mesmo com certa incompreensão, não somente pelo fato de a natureza ser reintroduzida na política, mas principalmente como objeto das ciências sociais. Com Sociedade contra a natureza (Editora Francisco Alves, 1985), originalmente lançado em 1972, a geração de estudantes universitários foi tomada de entusiasmo por seu pensamento, que, além de defender 0 feminismo, propunha uma nova conciliação entre o homem e a natureza. Este pensamento acabou tornando o livro um cult. Assim, seu segundo livro tratou do aspecto social da relação do homem com as forças materiais, consagrando um modo de pensar a sociedade com respeito à natureza: sociedade antinatural.

Em seu terceiro livro, Homens domésticos e homens selvagens (Livraria Bertrand, 1976), o autor mostra novamente que "foi a modernidade de fato que criou um tipo de sociedade antinatureza. Ela procura esvaziar o mundo de todo esplendor, de sua magia, procura desencantá-lo para deixar subsistir apenas o que é produto da ciência e da técnica. Mas os homens tão grossei ramente arrancados de seu paraíso, [...] aspiram a um novo saber sobre a natureza, preferem a unidadeà polaridade entre a sociedade e a natu- reza". Assim, "os homens não podem mais estar felizes numa sociedade antinatureza, e procuram sem descanso celebrar seu laço, restituir-Ihe força e magia, a fim de provar que outra sociedade pela natureza é possível".

Moscovici pode ser considerado um ecomarxista (ou ecossocial ista) , o que mais influenciou os movimentos estudantis dos anos 1960 (cf. Diegues, A. C. Mito moderno da natureza intocada. São Paulo: Hucitec, 1996). Os ecomarxistas partem da idéia de que a natureza é considerada um recurso transformado em mercadoria no sistema capitalista. Para eles, apenas uma nova organização da sociedade e do espaço geográfico, associada a um novo papel do Estado, criará as condições para o surgimento de uma nova relação homem/natureza, mais harmoniosa.

No ímpeto da crítica à vida cotidiana, à sociedade de consumo, ao produtivismo e ao cientificismo, entre outros, Moscovici mostrou a necessidade de pensar e fazer um mundo capaz de reciclar tanto seus recursos quanto sua história e saberes. Fazendo um relato do que era o mundo e do que ele se tornaria, o autor propôs desfragmentar o olhar, e, com ele, as ciências humanas, que viviam ainda no calor do positivismo, a se libertarem da diretriz estrutural-marxista. Suas idéias de base, no entanto, se dirigem a uma crítica à proposição entre culturalismo e naturalismo. Assim, declaradamente nos tirou do dilema "sociedade ou natureza" e da oposição cara aos antropólogos da natureza/cultura.

Final mente, partindo de uma frase de Moscovici, convidamos o leitor à reflexão: "O eterno retorno à natureza, visto sob o aspecto do desejo, significa voltar com nossos corpos ao corpo dos corpos, a terra, onde cada um encontra sua morada, nosso oïcos desde a origem dos tempos". 